\title{
SUPRAGLACIAL RE-SEDIMENTATION FROM MELT-WATER STREAMS ON TO SNOW OVERLYING GLACIER ICE, SYLGJUJÖKULL, WEST VATNAJÖKULL, ICELAND
}

\author{
By Julian A. Dowdeswell \\ (Institute of Arctic and Alpine Research and Department of Geography, University of Colorado, \\ Boulder, Colorado 80309, U.S.A.)
}

\begin{abstract}
Sediment deposition on to snow overlying glacier ice occurs in a marginal zone extending 200-300 m up-glacier from the terminus of Sylgjujökull. Debris on ice above the marginal snow zone comes from debris-rich layers, and $85 \%$ of this debris falls between 1 and $4 \phi$, the characteristic grain-size of volcanic ash within Icelandic glaciers. The ash is transported down-glacier as suspended load in melt-water streams at concentrations between 61 and $430 \mathrm{mg} \mathrm{l}^{-1}$, and loads from 0.2 to $32.7 \mathrm{~g} \mathrm{~s}^{-1}$. A diurnal hysteretic loop is present in the relationship between suspended sediment and discharge for one stream.

Supraglacial streams flow from relatively impermeable ice on to more permeable snow near the glacier terminus. As they move across the snow, stream discharge (up to $0.1 \mathrm{~m}^{3} \mathrm{~s}^{-1}$ on ice) is reduced and debris is resedimented as linear debris trains $1-3 \mathrm{~cm}$ thick and orientated orthogonal to the glacier margin. Since sediment deposition reduces the permeability of the snow substrate, the debris trains are successively extended across the snow cover at rates of up to $36.5 \mathrm{~m} \mathrm{~d}^{-1}$. If the debris is then let down on to glacier ice, linear dirt-cone assemblages may be produced. Re-sedimented debris trains are of little stratigraphic significance if deposited pro-glacially.
\end{abstract}

RÉSUMÉ. Resédimentation supraglaciaire à partir d'écoulements d'eaux de fusion sur la neige recouvrant la glace de glacier, au Sylgjujökull, dans l'Ouest du Vatnajökull, Istande. Un dépôt de sédiment sur la neige recouvrant la glace de glacier se produit dans une zone marginale s'étendant sur 200 à $300 \mathrm{~m}$ à l'amont du front du Sylgjujökull. Les sédiments sur la glace, au-dessus de la zone enneigée marginale proviennent de niveaux riches en sédiments, et $85 \%$ de ces sédiments ont entre 1 et $4 \phi$, la dimension caractéristique de la cendre volcanique dans les glaciers islandais. La cendre est transportée vers l'aval'du glacier sous forme de suspension dans les courants d'eau de fusion à des concentrations allant de 61 à $430 \mathrm{mg}$ par litre et avec des débits solides de 0,2 à $32,7 \mathrm{~g}$ par seconde. Dans le diagramme débrit/transport solide d'un courant on constate une boucle journalière d'hysteresis.

Les courants liquides superficiels coulent depuis la glace relativement imperméable, vers la neige plus perméable près du front glaciaire. Pendant son parcours à travers la neige, le débit liquide (jusqu'à $0,1 \mathrm{~m}^{3} / \mathrm{s}$ sur la glace) subit une réduction et les sédiments en suspension sont déposés en files linéaires de 1 à $3 \mathrm{~cm}$ d'èpaisseur orientés perpendiculairement à la bordure du glacier. Comme le dépôt de ces sédiments réduit la perméabilité de la neige sous-jacente, les alignements de sédiments s'accroissent peu à peu à travers la couche de neige à des vitesses allant jusqu'à $36,5 \mathrm{~m}$ par jour. Si le sédiment est alors déposé au contact de la glace de glacier, des systèmes de cones morainiques linéaires peuvent se former. Les alignements de sédiments redéposés n'ont que peu de signification stratigraphique dans une sédimentation proglaciaire.

Zusammenfassung. Supraglaziale Wiederablagerung aus Schmelzwasserströmen in Schnee über Gletschereis, Sylgjujökull, West Vatnajökull, Island. Ablagerung von Sedimenten in Schnee über dem Gletschereis tritt in einer Randzone auf, die sich 200-300 m gletscheraufwärts vom Ende des Sylgjujökulls erstreckt. Schutt auf dem Eis oberhalb der randlichen Schneezone stammt aus schuttreichen Schichten; $85 \%$ dieses Schuttes besitzt die charakteristische Korngrösse für vulkanische Asche innerhalf der isländischen Gletscher von 1-4 $\phi$ Durchmesser. Die Asche wird gletscherabwärts als suspendierte Fracht in Salzwasserströmen transportiert, bei Konzentrationen zwischen 61 und $430 \mathrm{mg}$ pro Liter und Frachtraten von 0,2 bis $32,7 \mathrm{~g}$ pro Sekunde. Zwischen der suspendierten Sedimentmenge und der Wasserführung eines Stromes besteht eine tägliche hysteretische Koppelung.

Nahe dem Gletscherende fliessen die oberflächlichen Ströme vom relativ undurchlässigem Eis in durchlässigen Schnee. Bei der Überquerung des Schnees wird die Wasserführung (auf Eis bis zu $0,1 \mathrm{~m}^{3}$ pro Sekunde) reduziert und der Schutt in 1-3 cm dicken Streifen, die senkrecht zum Gletscherrand orientiert sind, wieder abgelagert. Da die Schuttablagerung die Durchlässigkeit des Schneeuntergrundes vermindert, dehnen sich die Schuttstreifen 
allmählich mit Raten bis zu 36,5 m pro Tag über die Schneedecke aus. Senkt sich der Schutt dann auf das Gletschereis, so können sich lineare Ansammlungen von Schmutzkegeln bilden. Wiederabgelagerte Schuttstreifen besitzen geringe stratigraphische Bedeutung, wenn sie vor dem Gletscher auftreten.

\section{INTRODUCTION}

Most work concerning supraglacial debris melt-out, transport, and deposition (e.g., Sharp, 1949; Boulton, 1967, 1968; Eyles, 1979) has examined forms and processes which occur over an ice substrate. This paper describes supraglacial debris re-sedimentation on to snow overlying glacier ice in a zone extending 200-300 m up-glacier from the margin of Sygjujökull, Iceland, and the unusual depositional features that result.

During July 1979, debris-charged supraglacial streams flowed from bare ice on to the marginal snow zone and percolated into the snow, producing linear deposits (referred to as resedimented debris trains) orientated orthogonal to the glacier terminus. The marginal snow zone is accumulated from wind-drifted snow during the previous winter, and is similar to the snow accumulation and wind-drift ice-wedge formation described at the edge of two ice masses by Hooke (1970, 1973).

The term re-sedimentation (Lawson, 1979) is used because, while supraglacial sedimentation occurs at Sylgjujökull when material first melts out at the glacier surface, re-sedimentation takes place when debris is re-deposited on to the marginal snow zone after fluvial transportation downglacier.

Sylgjujökull is a surging outlet glacier of the Vatnajökull ice cap, Iceland (lat. $64^{\circ} 26^{\prime} \mathrm{N}$., long. $18^{\circ} 03^{\prime} \mathrm{W}$.), which is at present (1979) in the quiescent phase between surges (Fig. 1). During surges, the last of which occurred in 1945, the glacier is heavily crevassed in the ablation zone (Thorarinsson, 1964, 1969), and it is only in the quiescent phase when the glacier is largely stagnant (Freysteinsson, 1969) that a network of supraglacial streams develops.

\section{ORIGIN OF SUPRAGLACIAL DEBRIS}

The main source of debris on the bare ice surface of Sylgjujökull between the marginal snow zone and the transient snow-line (c. $1.5 \mathrm{~km}$ above the glacier terminus in mid-July 1979) is a series of debris-rich ice layers (Hambrey and Müller, 1978). These dip up-glacier at $15^{\circ}$ to $75^{\circ}$. They strike approximately parallel to the glacier front but also have fold axes parallel to the flow. Boulton (1970) has described similar folds in Borebreen, Olav V Land, Svalbard.

Sediment melting out of the debris-rich layers is thought to be locally derived volcanic ash (Steinthórsson, [1978]) deposited on the surface of Vatnajökull and subsequently buried by snowfall. The ash is later exposed in the ablation zone as debris-rich layers within glacier ice. At Sylgjujökull, sediment released from the debris bands by ablation was black, with $85 \%$ of particles in the range $1-4 \phi$. Similar grain-size distributions and colour have been found for volcanic ash melting out of glacier ice by Kozarski and Szupryczński (1973) at Sidujökull, and Boulton and Dent (1974) at Breiðamerkurjökull (Fig. 1a).

At the ice surface, larger particles were confined to the lateral margins of the glacier, and to a zone $250-400 \mathrm{~m}$ wide at the ice front. In the former situation, they are derived from the nunataks to the north and south of Sylgjujökull and, in the latter, their sub-rounded form suggests a basal origin (Boulton, 1978). These coarse fragments were not involved in melt-water stream transport or re-sedimentation to form debris trains. 


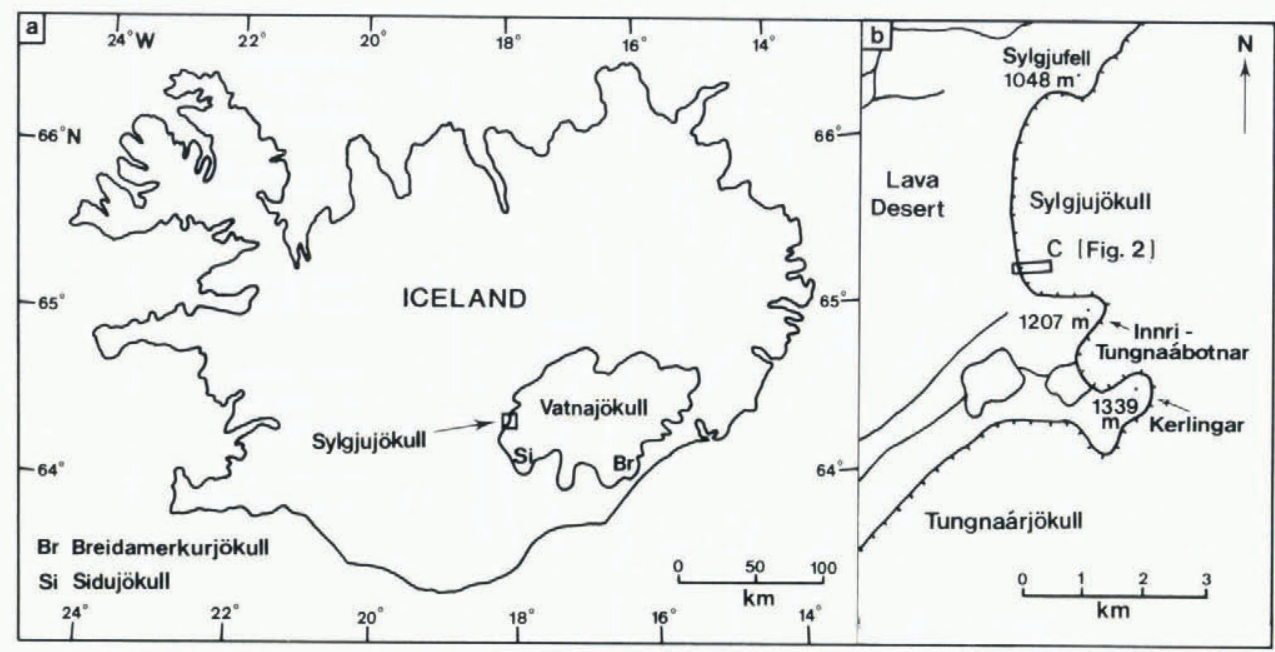

Fig. I. (a) Location of Sylgjujökull within Iceland. (b) Location of Sylgjujökull at the western margin of Vatnajökull.

\section{DEBRIS TRANSPORT IN SUPRAGLACIAL MELT-WATER STREAMS}

After release from the ablating ice, the ash is transported down-glacier in supraglacial meltwater streams. Suspended sediment concentration, supraglacial stream discharge, and suspended sediment load were measured in nine streams at points c. $500 \mathrm{~m}$ up-glacier (Fig. 2). Sediment concentrations were assessed using a depth-integrating sampler (Gregory and Walling, 1973, p. 153), and each $200 \mathrm{ml}$ aliquot obtained was filtered and the sediment weighed later in the laboratory. Discharges were calculated from cross-sectional area and velocity measurements, while sediment load is the product of sediment concentration and discharge (Leopold and Maddock, 1953).

Data were collected over 5 days of relatively constant weather (Table I). Suspended sediment concentrations and discharge were measured for the period (12.00-15.00 h) of maximum ablation and stream flow each day. Readings throughout the 5-day period were averaged for each stream.

Table II records the results and it should be noted that, although suspended sediment concentration and load values are accurate in relative terms, their absolute accuracy is less certain. However, mean peak suspended sediment concentrations in the nine streams varied between 61 and $430 \mathrm{mg} \mathrm{l}^{-1}$, and are of the same order of magnitude as Nakawo's (1979) debris concentration of $87.8 \mathrm{mg} \mathrm{l}^{-1}$ in running water on the surface of G2 glacier, Nepal.

The map of the supraglacial drainage network on part of Sylgjujökull (Fig. 2) shows that streams 4,5 , and 6 do not reach the marginal snow zone down-glacier, but instead descend a moulin $270 \mathrm{~m}$ from the glacier margin. The mean peak suspended sediment concentration of streams (measured $500 \mathrm{~m}$ from the glacier terminus) that actually reach the marginal snow zone varies between 61 and $190 \mathrm{mg} \mathrm{l}^{-1}$; their discharges range from 0.003 to $0.107 \mathrm{~m}^{3} \mathrm{~s}^{-1}$, and their loads between 0.2 and $20.3 \mathrm{~g} \mathrm{~s}^{-1}$. Measurements $200-300 \mathrm{~m}$ from the marginal snow zone are thought to reflect sediment transport to the debris trains because little stored sediment was observed in stream channels between the sample points and the snow zone during high day-time discharge. 


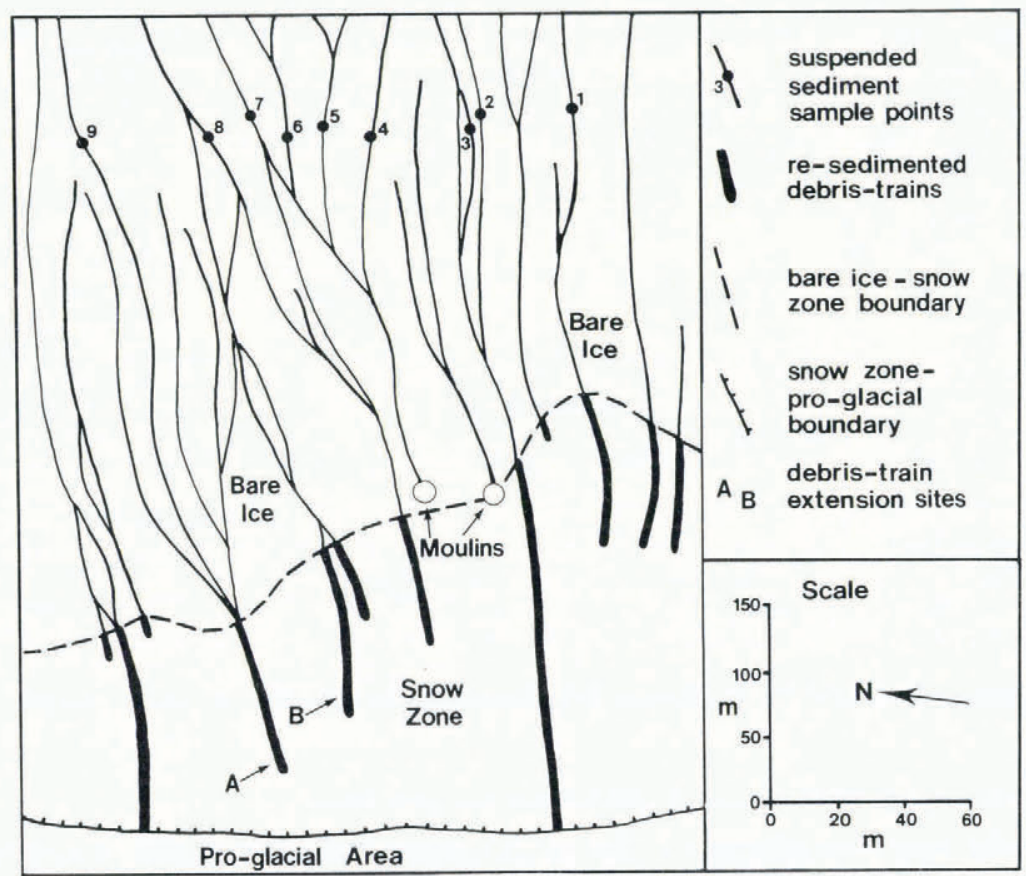

Fig. 2. Supraglacial melt-stream network and pattern of re-sedimented debris-train development. Bare ice gives way to snow down-glacier. Figure l locates the study area on Sylgjujökull. Note that horizontal and vertical scales are different.

The behavior of stream 7 was examined in some detail. The suspended sediment concentration and discharge varies diurnally (Fig. 3), implying that sediment delivery to the marginal snow zone exhibits a daily rhythm. Lack of data for any stream over a 24 -h period precludes examination of the total daily sediment delivery to the snow zone. A diurnal hysteretic loop in the relationship between suspended sediment concentration and discharge is also present (Fig. 4). The clockwise hysteretic loop shows that greater sediment concentrations occur on the rising limb of the diurnal hydrograph than at equivalent discharges during the falling stage. This may indicate a diurnal flushing out of debris stored in the channel during low night-time discharge. However, a greater amount of data concerning suspended sediment concentrations

TABLE I. MEAN 12.00-15.00 h AIR TEMPERATURE AND CLOUD COVER, 21-25 July 1979, AT SyLGJujÖKULl

$\begin{array}{lcc}\text { Date } & \begin{array}{c}\text { Mean } 12.00-15.00 h \\ \text { air temperature }\end{array} & \begin{array}{c}\text { Mean } 12.00-15.00 h \\ \text { cloud cover } \\ 1 / 8 \text { ths }\end{array} \\ \text { 21 July } & 8.5 & 4 / 8 \\ \text { 22 July } & 6.5 & 1 / 8 \\ \text { 23 July } & 6.8 & 1 / 8 \\ \text { 24 July } & 6.1 & 5 / 8 \\ \text { 25 July } & 8.2 & 1 / 8\end{array}$


TABLE II. MEAN PEAK (12.00-15.00 h) SUSPENDED SEDIMENT CONCENTRATION, MELTWATER DISCHARGE, AND SUSPENDED SEDIMENT LOAD MEASUREMENTS FOR NINE SUPRAGLACIAL STREAMS, 21-25 JULY 1979 (SAMPLING POINTS ARE LOCATED IN FIGURE 2)

$\begin{array}{ccccc}\text { Stream } & \begin{array}{c}\text { Mean peak } \\ \text { sediment } \\ \text { concentration } \\ \mathrm{mg} \mathrm{1}^{-1}\end{array} & \begin{array}{c}\text { Mean peak } \\ \text { discharge }\end{array} & \begin{array}{c}\text { Mean peak } \\ \text { sediment } \\ \text { load } \\ \mathrm{g} \mathrm{s}^{-1}\end{array} & \begin{array}{c}\text { Number of } \\ \text { samples }\end{array} \\ 1 & 82 & \mathrm{~m}^{3} \mathrm{~s}^{-1} & 1.1 & \\ 2 & 82 & 0.013 & 0.2 & 2 \\ 3 & 77 & 0.003 & 1.7 & 2 \\ 4 & 210 & 0.022 & 18.9 & 2 \\ 5 & 430 & 0.090 & 32.7 & 6 \\ 6 & 150 & 0.076 & 2.4 & 2 \\ 7 & 190 & 0.016 & 20.3 & 6 \\ 8 & 110 & 0.107 & 8.8 & 2 \\ 9 & 61 & 0.080 & 2.0 & 2\end{array}$

must be obtained before generalizations relating to diurnal hysteretic effects may be made for supraglacial streams.

\section{RE-SEDIMENTED DEBRIS TRAINS}

A series of re-sedimented debris trains (Fig. 5) was observed in the marginal snow-covered zone at Sylgjujökull (Fig. 2). They are composed of a $1-3 \mathrm{~cm}$ veneer of debris overlying snow. After initial deposition, differential ablation raises the debris trains relative to the general snow

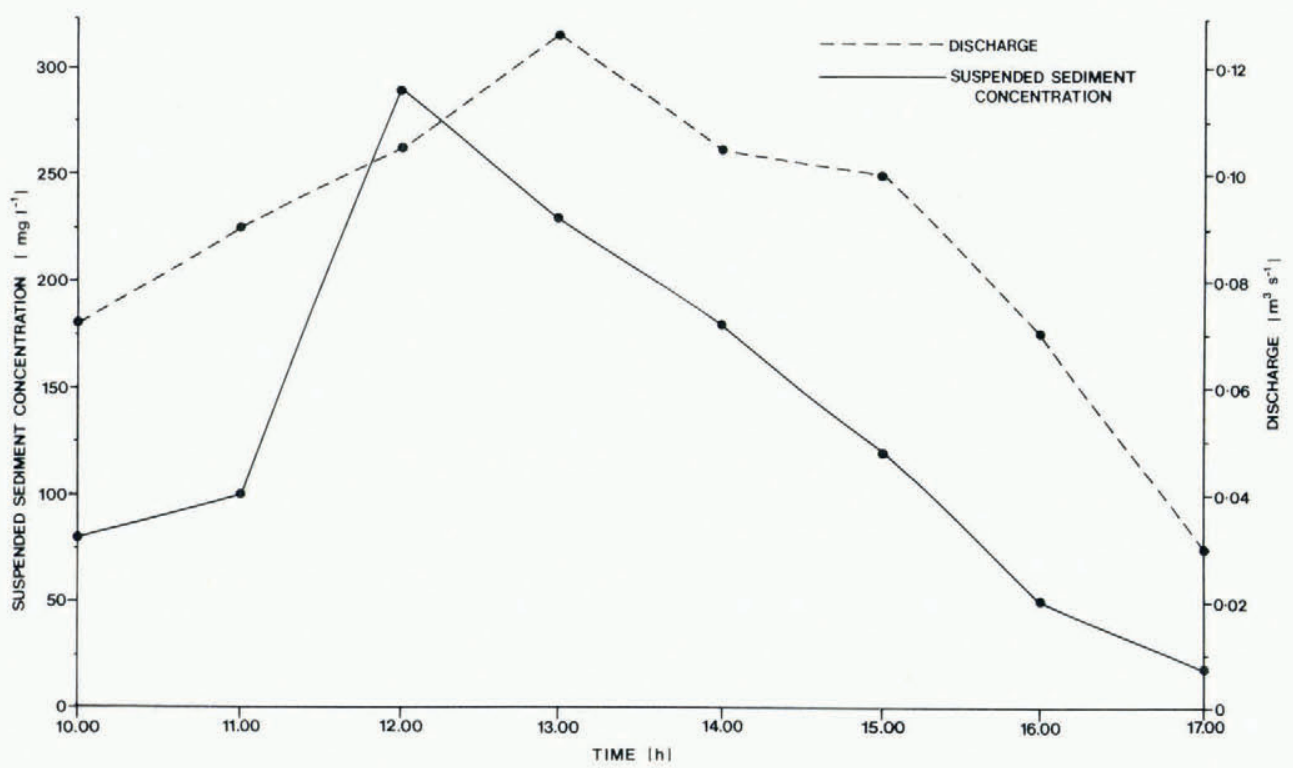

Fig. 3. Suspended sediment concentration and melt-water discharge from stream 7 (Fig. 2) on 21 July 1979 between 10.00 and $17.00 \mathrm{~h}$. 


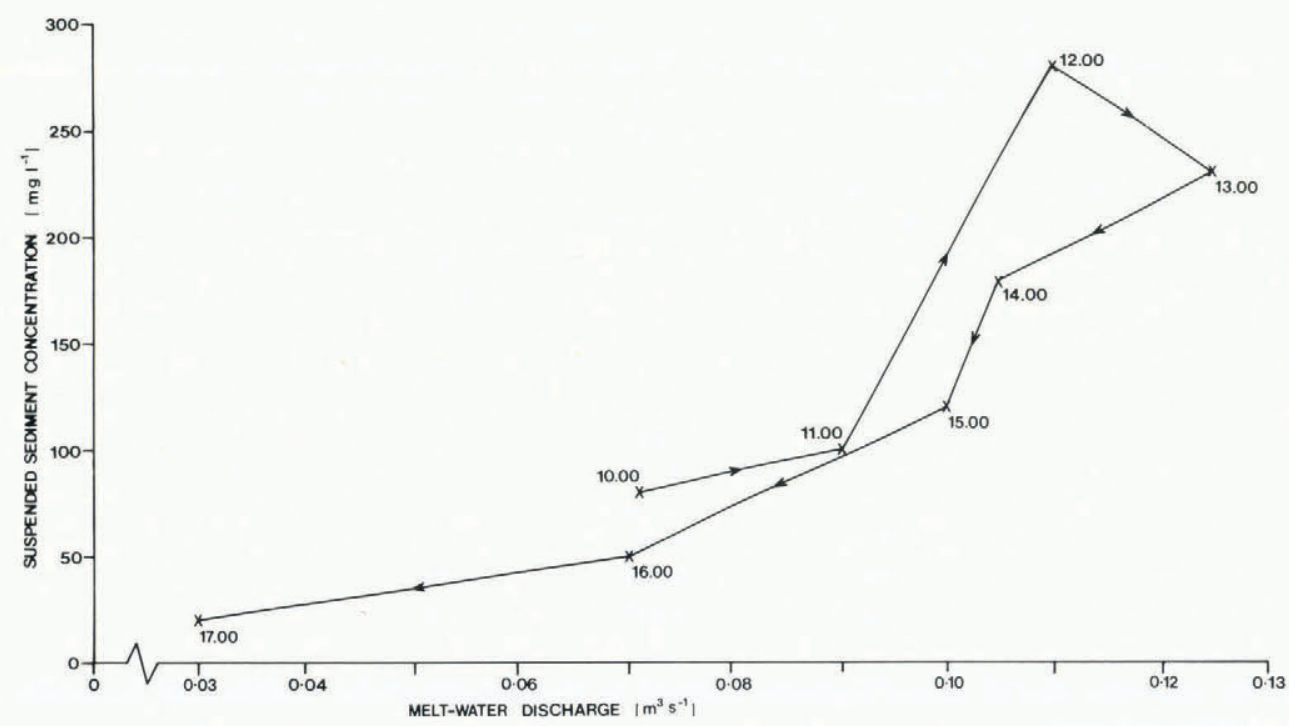

Fig. 4. The relationship between suspended sediment concentration and discharge. Note the hysteretic effect. Data from stream 7 (Fig. 2) on 21 July 1979 between 10.00 and 17.00 h. The data are the same as for Figure 3.

surface. $78 \%$ of the sediment within the debris trains was between 1 and $4 \phi$, compared with $85 \%$ of material within the same size range in debris-rich layers up-glacier. This particle-size evidence, combined with that concerning suspended sediment concentrations and load in supraglacial streams, suggests that the debris comprising re-sedimented debris trains comes from the debrisrich layers cropping out in the ice higher on the glacier.

Melt-water streams transporting suspended sediment flow from a relatively impermeable ice substrate on to much more permeable snow at between 200 and $300 \mathrm{~m}$ from the ice margin (Fig. 2). On snow, the streams lose surface discharge as water percolates into the snow, and the suspended sediment is deposited on to the snow surface. The differential permeability of snow and ice is the key factor leading to debris re-sedimentation.

Daily amounts of re-sedimented debris-train extension and $14.00 \mathrm{~h}$ air temperatures were recorded at two sites (Fig. 2) during a 4-day study period (14-17 July). Only one day showed little debris-train extension $(<1.0 \mathrm{~m})$, and this coincided with the lowest $14.00 \mathrm{~h}$ air temperature $\left(2.8^{\circ} \mathrm{C}\right)$. On other days, debris-train extension ranged from 11.5 to $36.5 \mathrm{~m}$, in association with $14.00 \mathrm{~h}$ air temperatures of between 3.9 and $6.4{ }^{\circ} \mathrm{C}$. The highest amount of daily extension coincided with the highest $14.00 \mathrm{~h}$ air temperature. Meier and Tangborn (1961) and Gudmundsson and Sigbjarnarson (1972) both considered air temperatures an important factor influencing glacier run-off.

While re-sedimented debris-train initiation is dependent on differences in permeability between ice and snow, continued debris-train extension requires the further permeability contrast between snow and the sand-size material of the re-sedimented debris trains. Figure 6 illustrates this; water flows over re-sedimented debris, where permeability is less than on the surrounding snow. Debris-train extension is therefore suggested to involve a positive feed-back loop, wherein debris re-sedimentation reduces permeability in the snow zone, allowing further extension to occur. Debris-train extension may continue until the glacier margin is reached (Fig. 2). 


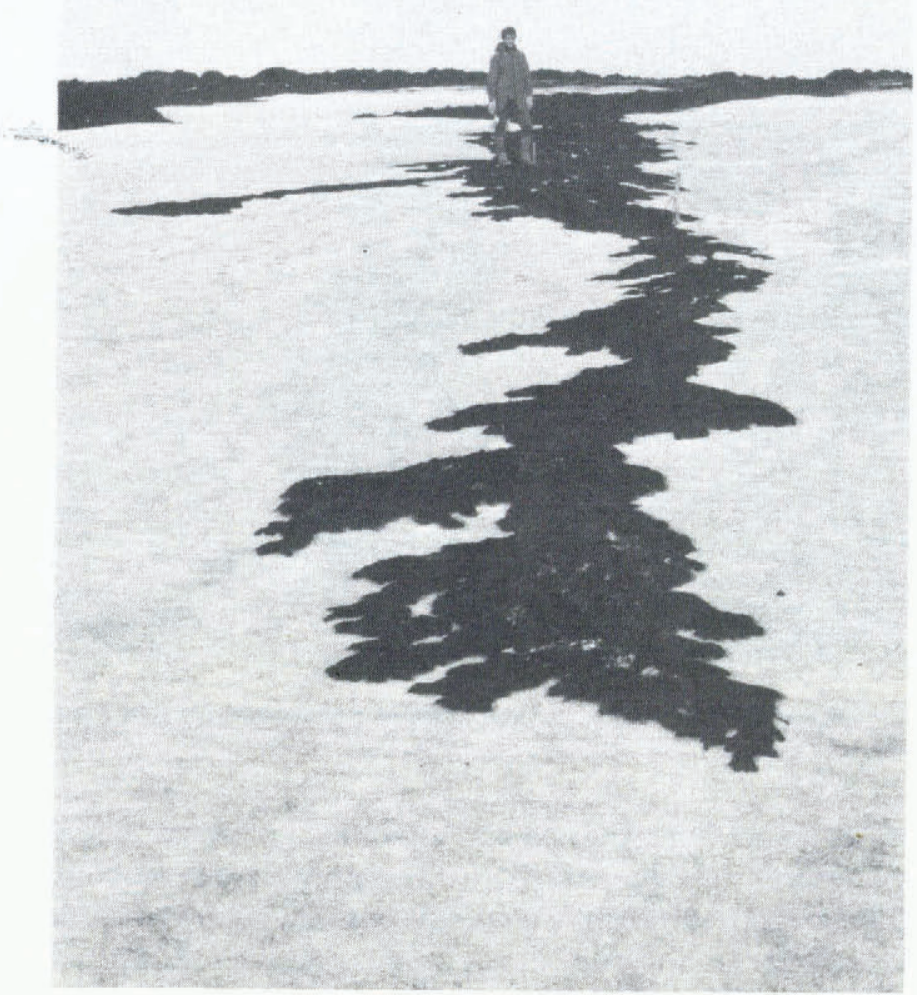

Fig. 5. A re-sedimented debris train orientated orthogonal to the glacier margin, Sylgjujokull. Note that the feature has developed on snow overlying glacier ice.

Several melt-water channels were observed in the snow zone, associated with re-sedimented debris trains (Fig. 7). Within the pools or basins in the channel reach, a layer of sediment is seen. Over the riffles or bars a film of refrozen ice conceals sediment. However, its presence was confirmed by probing. It is thought that refrozen melt water and sediment in combination allow channel flow to continue on the otherwise relatively permeable snow substrate.

\section{IMPLICATIONS FOR PRO-GLACIAL DEPOSITION}

As Sylgjujökull retreats between surges, re-sedimented supraglacial debris is deposited on to the till surface at the glacier marign. However, there are at least three reasons why this sediment is likely to be of little significance to the final glacial stratigraphy of the pro-glacial area. First, resedimented debris trains at Sylgjujökull are only $1-3 \mathrm{~cm}$ thick, and are discrete linear forms covering less than $10 \%$ of the marginal snow-zone surface. Secondly, a number of pro-glacial 


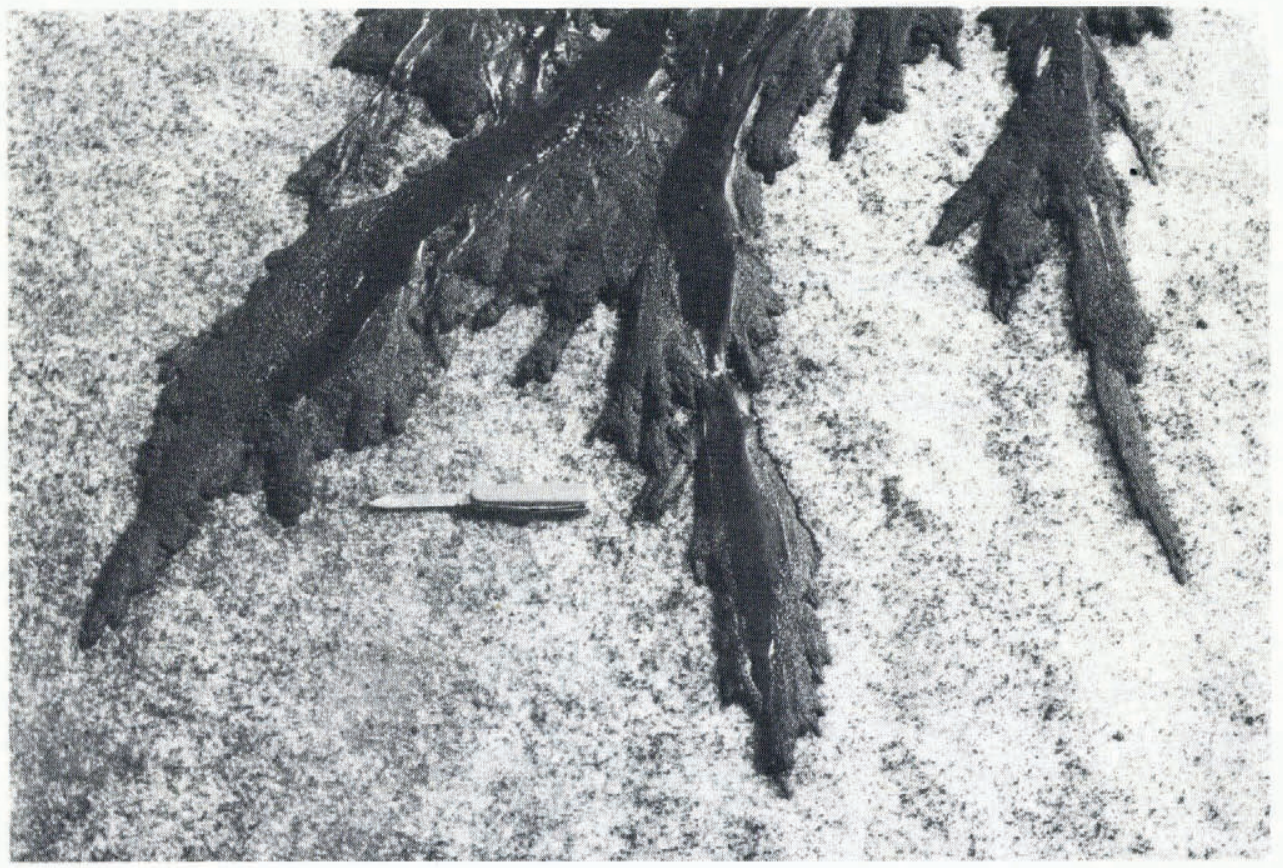

Fig. 6. Water flowing in unchannelled form on top of re-sedimented debris overlying snow. The permeability is less on the debris cover than on the snow, allowing debris-train extension.

streams run parallel to the ice front and directly adjacent to it, therefore removing much of the re-sedimented debris. Thirdly, if Clapperton's (1975) suggestion that much pro-glacial sediment is entrained during the surging of Icelandic glaciers is correct, the fines deposited in the quiescent period between surges would be re-worked during the surging phase of the cycle.

Boulton and Dent (1974), working at Breiðamerkurjökull (Fig. 1), also found that supraglacial debris derived from volcanic ash and deposited on to the pro-glacial till made no significant contribution to total pro-glacial sedimentation.

\section{IMPLICATIONS FOR DIRT-CONE DEVELOPMENT}

At Sylgjujökull immediately up-glacier of the marginal snow zone, linear dirt-cone assemblages trending orthogonal to the glacier margin were noted. It is suggested that, as the snow-ice boundary at the up-glacier edge of the snow zone retreats down-glacier during the summer (analogous to the up-glacier retreat of the transient snow-line), linear debris trains are let down on to bare ice. This leads to the formation of linear swarms of dirt cones as a result of differential ablation, and provides an alternative explanation of the linear arrangement of dirt cones to that involving direct deposition on the beds of melt-water channels (e.g. Lewis, 1940; Swithinbank, 1950; Knighton, 1973).

However, three points must be noted. First, no systematic observations were made at Sylgjujökull of this transition from debris trains to dirt cones. Secondly, the hypothesis cannot explain all the dirt cones on Sylgjujökull but only the linear assemblages immediately up-glacier 


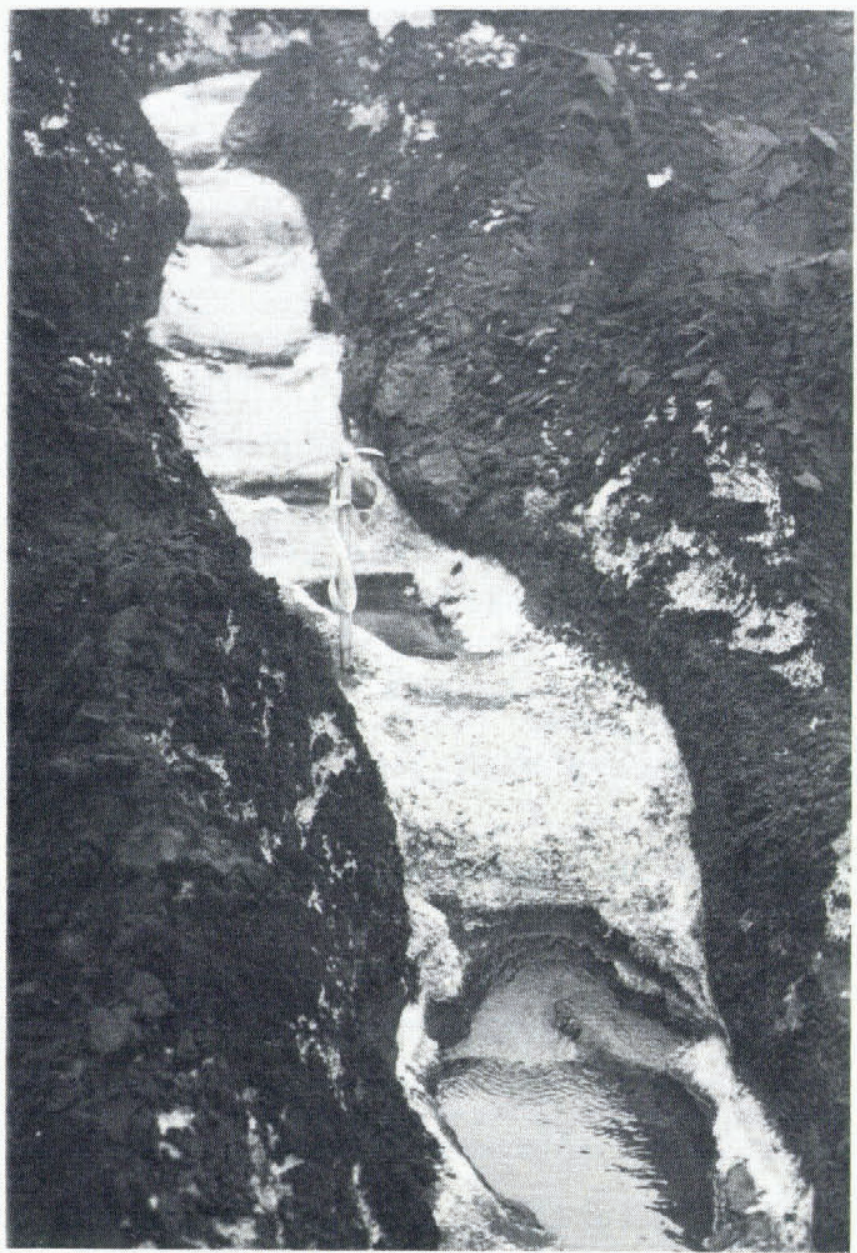

Fig. 7. Melt-water channel in the snow zone low on Sylgjujökull, showing exposed sediment layers in pools and refrozen ice over bars. The photograph was taken at $19.00 \mathrm{~h}$ when little water was present.

of the marginal snow zone. Finally, the hypothesis does not affect the proposition that some dirt cones may also develop as a result of debris deposition on stream beds.

\section{Conclusions}

Re-sedimented debris trains form only when:

i. There is a snow zone on the margin of the glacier snout.

ii. The snout is relatively free of crevasses and moulins, allowing a supraglacial drainage network to develop.

iii. There is a debris source of sand-size or finer material, which may be transported in melt streams. 
At Sylgjujökull, these conditions are fulfilled because:

i. Wind-drifting of snow builds up a marginal snow zone. However, it is not known whether such a zone is formed every year or less regularly.

ii. The glacier is stagnant and in the quiescent period between surges. It, therefore, has few fissures relative to its surface while surging.

iii. Volcanic debris becomes supraglacial in the ablation area to provide a source of fine sediment.

All three of the above conditions will not often be met. It is because of this that the linear depositional forms observed at Sylgjujökull, termed re-sedimented debris trains, have not been reported before.

\section{ACKNOWLEDGEMENTS}

The author wishes to thank Drs J. Andrews, N. Caine, and M. Hambrey for their comments on early drafts of this paper, and M. Sharp for both discussion and aid in planning the 1979 Cambridge Sylgjujökull Expedition. Financial assistance from Jesus College, Cambridge, and the David Richards Fund, University of Cambridge, is gratefully acknowledged. The members of the Cambridge Sylgjujökull Expedition, 1979, rendered considerable aid in the field. The National Research Council of Iceland kindly granted permission for this project to be carried out.

MS. received 4 November 1980 and in revised form 6 April 1981

\section{REFERENCES}

Boulton, G. S. 1967. The development of a complex supraglacial moraine at the margin of Sørbreen, Ny Friesland, Vestspitsbergen. Journal of Glaciology, Vol. 6, No. 47, p. 717-35.

Boulton, G. S. 1968. Flow tills and related deposits on some Vestspitsbergen glaciers. Journal of Glaciology, Vol. 7, No. 51 , p. $391-412$.

Boulton, G. S. 1970. On the origin and transport of englacial debris in Svalbard glaciers. Journal of Glaciology, Vol. 9, No. 56, p. 213-29.

Boulton, G. S. 1978. Boulder shapes and grain size distribution of debris as indicators of transport paths through a glacier and till genesis. Sedimentology, Vol. 25, No. 6, p. 773-99.

Boulton, G. S., and Dent, D. L. 1974. The nature and rates of post-depositional changes in recently deposited till from south-east Iceland. Geografiska Annaler, Vol. 56A, Nos. 3-4, p. 121-34.

Clapperton, C. M. 1975. The debris content of surging glaciers in Svalbard and Iceland. Journal of Glaciology, Vol. 14, No. 72 , p. $395-406$.

Eyles, N. 1979. Facies of supraglacial sedimentation on Icelandic and Alpine temperate glaciers. Canadian Journal of Earth Sciences, Vol. 16, No. 7, p. 1341-61.

Freysteinsson, S. 1969. Tungnárjökull. Jökull, Ár 18, 1968, p. 371-88.

Gregory, K. J., and Walling, D. E. 1973. Drainage basin form and process. London, Edward Arnold.

Gudmundsson, G., and Sigbjarnarson, G. 1972. Analysis of glacier run-off and meteorological observations. Journal of Glaciology, Vol. 11, No. 63, p. 303-18.

Hambrey, M. J., and Müller, F. 1978. Structures and ice deformation in the White Glacier, Axel Heiberg Island. Northwest Territories, Canada. Journal of Glaciology, Vol. 20, No. 82, p. 41-66.

Hooke, R. L. 1970. Morphology of the ice-sheet margin near Thule, Greenland. Journal of Glaciology, Vol. 9, No. 57. p. 303-24.

Hooke, R. L. 1973. Flow near the margin of the Barnes Ice Cap, and the development of ice-cored moraine. Geological Society of America. Bulletin, Vol. 84, No. 12, p. 3929-48. 
Knighton, A. D. 1973. Grain-size characteristics of superglacial dirt. Journal of Glaciology, Vol. 12, No. 66, p. 522-24. [Letter.]

Kozarski, S., and Szupryczński, J. 1973. Glacial forms and deposits in the Sidujökull deglaciation area. Geographia Polonica, Vol. 26, p. 255-311.

Lawson, D. E. 1979. Sedimentological analysis of the western terminus region of the Matanuska Glacier, Alaska. U.S. Cold Regions Research and Engineering Laboratory. Report 79-9.

Leopold, L. B., and Maddock, T., jr. 1953. The hydraulic geometry of stream channels and some physiographic implications. U.S. Geological Survey. Professional Paper 252.

Lewis, W. V. 1940. Dirt cones on the northern margins of Vatnajökull, Iceland. Journal of Geomorphology, Vol. 3. No. i, p. 16-26.

Meier, M. F., and Tangborn, W. V. 1961. Distinctive characteristics of glacier runoff. U.S. Geological Survey. Professional Paper 424-B, p. B-14-B-16.

Nakawo [i.e. Nakao], M. 1979. Supraglacial debris of G2 glacier in Hidden Valley, Mukut Himal, Nepal. Journal of Glaciology, Vol. 22, No. 87, p. 273-83.

Sharp, R. P. 1949. Studies of superglacial debris on valley glaciers. American Journal of Science, Vol. 247, No. 5, p. 289-315.

Steinthórsson, S. [1978.] Tephra layers in a drill core from the Vatnajökull ice cap. Jökull, Ár 27, 1977, p. $2-27$.

Swithinbank, C. W. M. 1950. The origin of dirt cones on glaciers. Journal of Glaciology, Vol. 1, No. 8, p. 439, $461-65$.

Thorarinsson, S. 1964. Sudden advance of the Vatnajökull outlet glaciers 1930-1964. Jökull, Ár 14; p. 76-89.

Thorarinsson, S. 1969. Glacier surges in Iceland, with special reference to the surges of Brúarjökull. Canadian Journal of Earth Sciences, Vol. 6, No. 4, Pt. 2, p. 875-82. 